\title{
(c) (1) \\ O MAL, O DIABO E OS AGENTES ESVAZIADORES DO BEM NA DOUTRINA CATÓLICA
}

\author{
Evil, the devil and workers become empty well in catholic doctrine
}

\author{
Marco Antonio Marcon \\ Mestrando do Programa de Teologia \\ da Pontifícia Universidade Católica do Paraná - Brasil, marcon777@ gmail.com.
}

\begin{abstract}
RESUMO: O objetivo deste trabalho é conceituar o mal e o Diabo sob os olhos da doutrina da Igreja Católica, assim como debater sobre a incoerência dogmática que pode surgir caso estes elementos sejam retirados ou negligenciados no ensino básico desta fé. A diversidade no pensamento teológico por vezes flerta com os limites, que chega a rejeitar tais temas, talvez constrangidos pelo que se tornou a imagem destes Esvaziadores do bem no decorrer dos séculos e principalmente na modernidade. No entanto, a identidade religiosa se cria quando expõe para o mundo plural seus elementos de crenças mais peculiares e particulares. A maior vergonha está na falta de originalidade em alguma expressão religiosa, querendo com tamanha obsessão se adaptar ao mundo, que perde a própria identidade.
\end{abstract}

Palavras-chave: Diabo; Igreja Católica; mal.

ABSTRACT: The aim of this paper is to conceptualize evil and the devil under the eyes of the Catholic Church doctrine and discuss the dogmatic inconsistency that can arise if these elements are withdrawn or neglected in the basic teaching of this faith. The diversity in theological thinking sometimes flirts with the boundaries, which reaches out such issues, perhaps embarrassed by what has become the image of these Depleters well over the centuries and especially in modernity, however religious identity is created when exposed to the world plural elements of its most peculiar and particular beliefs. The greatest shame is the lack of originality in some religious expression, such obsession with wanting to fit so that the world loses identity of this development to the close relationship between religious media and the market ideology.

Key-words: Devil; Catholic Church; evil 
1. Introdução e contexto histórico

O tema deste artigo cabe graves elaborações filosóficas, primeiro em torno do que é o mal e depois o que é o diabo, não somente na Tradição Católica, mas também o que estes símbolos dizem na história e na sociedade de hoje. A Igreja Católica no decorrer dos seus 16 séculos $^{1}$ de existência exerceu sérias influências no imaginário das sociedades humanos, principalmente do ocidente. Este imaginário muitas vezes vinha desacompanhado de instrução, visto que a grande maioria das pessoas não era alfabetizada. As elaborações teológicas, com refinado grau intelectual ${ }^{2}$, chegavam até o cidadão comum pedagogicamente de forma simplificada: nas imagens poéticas das biografias dos santos e manuais, para os poucos que sabiam ler, e nas decorações das Igrejas com pinturas e esculturas para os não letrados. Na baixa e na alta idade média a evolução da arte, com a inspiração na catequese da massa convertida ao Cristianismo, foi responsável por formar a conceituação teológica popular em torno do mal e da figura que o representaria, o Diabo. Isto reforçado pelo fato que as missas raramente eram na língua que todos entendiam, principalmente com a queda do Império Romano do ocidente em 476 d.C., os chamados "povos bárbaros" vinham com sua própria linguagem e foram incorporados nas comunidades religiosas. $\mathrm{O}$ grego koine e agora $\mathrm{o}$ latim não conseguiam mais cumprir com a missão de universalizar estes ensinamentos nas comunidades, que agora eram grandes volumes de convertidos em conjunto com a adesão do seu governante a nova religião. Podemos imaginar a massa de analfabetos, com línguas diversas participando de uma missa onde o padre celebrava em latim. Numa catedral recheada de esculturas e pinturas belíssimas além dos símbolos próprios da celebração, certamente passavam uma mensagem, que não era exatamente aquela num nível teológico, fixando um conhecimento que se tornava popular, construído com as impressões recebidas da arte exposta e o imaginário trazido de suas próprias influências religiosas. A instrução pictórica marcou o ensino-aprendizagem da fé até o

\footnotetext{
${ }^{1}$ Considerando a data de sua fundação institucional na oficialização do Cristianismo como religião do Império Romano (397 d.C), a data de fundação moral e teológico considera-se o acontecimento histórico Jesus Cristo, mais precisamente após a paixão e ressurreição há 20 séculos ano 33 d. C., isto também por ser depositária da maior parte da documentação conhecida sobre a formação das primeiras Igrejas e textos que compuseram o Novo testamento.

${ }^{2}$ Os conceitos teológicos do cristianismo foram amadurecidos a graves penas nos primeiros 4 séculos de perseguição no ceio do Império Romano. Os apologetas (defensores da fé) deveriam defender a pertinência desta fé com alto grau de refinamento filosófico e de retórica, para sequer serem ouvidos pelo senado romano, um dos primeiros exemplos disso foi em Justino (+165 d.C.). Posteriormente as escolas da fé em Roma e Alexandria, como principais centros culturais, no século IV, V e VI aprofundaram as questões que seriam dogmas perenes da fé cristã.
} 
século XX, onde a escolarização se tornou prioridade dos governos, as celebrações puderam ser realizadas na língua local e da mesma forma a autorização para tradução da Bíblia chegando às mãos dos fiéis.

A parte desta realidade da grande massa, os chamados "padres da Igreja"3 debruçavam-se sobre a Bíblia e buscavam entender o que era esta Revelação da Verdade, buscavam elaborar racionalmente este acontecimento Jesus Cristo. Para isto se utilizavam de todos os recursos à disposição, desde o conhecimento das línguas originárias do Antigo e Novo Testamento ${ }^{4}$ aos conhecimentos disponíveis da filosofia. Alexandria, como grande centro cultural, serviu de base para muitos destes "Padres da Igreja" ${ }^{\circ}$, posteriormente os estudos foram descentralizados para os diversos Monastérios de onde surgiram as escolas e atuais universidades. ${ }^{6}$ Nestes debates filosóficos a cerca das revelações da fé por vezes formavam-se grupos com determinadas linhas teológicas discordantes, que poderiam receber a alcunha de hereges ${ }^{7}$. E assim em meio a convulsões intelectuais a doutrina católica ganhou corpo no decorrer dos séculos, este corpo pode ser chamado Tradição e o correto ensino desta é atribuído ao Magistério, que tem no colegiado de Bispos e dos Cardeais encabeçado pelo Papa a referência para todo povo de Deus. ${ }^{8}$

2. Controvérsias sobre o diabo e o mal na igreja católica

No século IV São João Crisóstomo, bispo e doutor da Igreja, escreveu aos cristãos de Antioquia, na segunda homília do seu De diabolo tentatore: "Na verdade, não me dá prazer falar-lhes do diabo; mas a doutrina que é consequência dessa realidade será muito útil para vós".

$\mathrm{Na}$ teologia cristã se busca discutir Deus à luz das Sagradas Escrituras. "A Doutrina da fé ou Palavra de Deus se encontra concretamente na Sagrada Escritura, lida

\footnotetext{
${ }^{3}$ Grandes pensadores do cristianismo, membros da hierarquia eclesiástica, que contribuíram nos primeiros 6 séculos para elaboração dos principais dogmas de fé e a formação da base doutrinária para o ensino, que tem o centro na profissão de fé chamada de Creio: "Creio em Deus Pai todo poderoso, Criador do céu e da terra e em Jesus Cristo seu único filho Nosso Senhor, nasceu da virgem Maria, padeceu sob Poncio Pilatos, morreu e foi sepultado, desceu a mansão dos mortos, ressuscitou ao terceiro dia, subiu aos céus. Está sentado a direita de Deus Pai todo poderoso, donde a de julgar os vivos e os mortos. Creio na Santa Igreja Católica, na comunhão dos santos, na remissão dos pecados, na ressurreição da carne, na vida eterna. Amem"

${ }^{4}$ Hebraico/Aramaico e Grego Koine respectivamente.

${ }^{5}$ Clemente, Origenes, Athanasio, Cirilo.

${ }^{6}$ A primeira universidade foi fundada pela Igreja Católica em Bolonha aos pés do mosteiro de mesmo nome no ano 1088 d.C. os primeiros cursos ofertados, foram teologia, artes, medicina e direito.

${ }^{7}$ Pessoas que se opunham ao status quo doutrinário, principalmente em relação a dogmas estabelecidos. Nos primeiros séculos a divindade de Jesus e a Salvação através de esforços pessoais foram as mais controversas e foco de heresias. O Concílio de Nicéia e no mesmo século Santo Agostinho combateram o Arianismo e o Pelagianismo, anteriormente formas de gnosticismo.

${ }^{8}$ Povo de Deus: assim são chamados todos que congregam a mesma fé em Jesus Cristo. A dignidade do batismo se estende a todos os cristãos igualmente o que se difere são as incumbências ou os carismas, o fato de estarem a serviço gera autoridade.
} 
e tradicionada na e pela comunidade eclesial" (BOFF, 2009, p.124). Desta forma, qualquer estudo num tema teológico, dentro da Igreja Católica, tem um rigor metodológico, um critério. O entendimento sobre o mal e sobre o Diabo deve ser esclarecido à luz das Sagradas Escrituras e com os óculos da fé serão elaboradas intuições através dos séculos, nas reflexões teológicas eclesiais. Sempre é bom lembrar que cada conhecimento humano é pertencente a sua classe de investigação, este artigo tem como fim esclarecer sobre o problema do mal e sobre as criaturas espirituais que praticam o mal apresentadas na doutrina cristã católica, então seguirá uma metodologia teológica com esta base.

Além de ser um problema em si mesmo, a questão Satã criou um problema entre os teólogos e por consequência na pastoral. ${ }^{9}$ Nos tempos atuais o fiel cristão encontra-se em dificuldades quando surge este tema. O constrangimento é evidente, talvez porque esta criatura não é agradável ou porque é vista como algo folclórico ou pelo simples fato de sua realidade ter ficado restrita aos filmes de terror.

A cultura moderna hedonista trata o diabo como garoto propaganda de produtos cult. Assim como utiliza a palavra pecado de forma positiva, para atrair a juventude à idolatria do prazer. As questões semânticas, para o que direcionar o medo, ao que identificar o mal, pode-se entender a adaptação num meio social secular avesso a doutrinas religiosas. No entanto, por qual razão o desconforto em tratar do tema Satan (hebraico), Diábolos (grego), Lúcifer (latin) nos dias de hoje, no meio teológicoeclesial? Se o combate espiritual não parte da primeira criatura rebelde às Leis de Deus, aquele velho Inimigo que tentou os primeiros pais e continua agindo, partirá de onde? Estas questões inquietam as igrejas, pois, ao mesmo tempo, que o catolicismo deixa este assunto de lado, o crescimento das igrejas protestantes, pentecostais e neo-pentecostais ${ }^{10}$ utilizando este mesmo tema, de forma recorrente, preenche a necessidade de reposta do fiel.

Por fim, este trabalho terá a tarefa de diferenciar os conceitos de mal e da criatura Diabo, pois se questiona em diversos graus dentro da Igreja moderna até mesmo sua existência. "Algo que até então não ocorreu na história do cristianismo"

\footnotetext{
${ }^{9}$ Pastoral é a forma com que a instituição cristã chama as ações dentro da Igreja, normalmente são formadas por grupos de fiéis não religiosos, chamados leigos, encabeçada por um padre.

${ }^{10}$ Protestante: Igreja Luterana, Calvinista, Anglicana e Batista.

Pentecostais: Assembleia de Deus, Igreja quadrangular e Deus é amor.

Neo-pentecostais: Igreja Univesal do Reino de Deus, Igreja da Graça de Deus, Bola de Neve e Igreja Mundial.
} 
(BALDUCCI, 2004, p.11). Isto se opõe ao ensino mais básico dos Papas e do atual Catecismo da Igreja Católica de 1992, este solicitado pelo Sínodo de 1985 justamente para sintonizar os ensinamentos das igrejas locais:

[...] a 25 de janeiro de 1985, convoquei uma Assembléia Extraordinária do Sínodo dos Bispos, por ocasião do vigésimo aniversário do encerramento do Concilio. A finalidade desta Assembléia era celebrar as graças e os frutos espirituais do Concílio Vaticano II, aprofundar o seu ensinamento para aderir melhor a ele e promover o conhecimento e a aplicação do mesmo. Nessa ocasião, os Padres sinodais afirmaram: "Muitíssimos expressaram o desejo de que seja composto um Catecismo ou compêndio de toda a doutrina católica, tanto em matéria de fé como de moral, para que ele seja como um ponto de referência para os catecismos ou compêndios que venham a ser preparados nas diversas regiões. A apresentação da doutrina deve ser bíblica e litúrgica, oferecendo ao mesmo tempo uma doutrina sã e adaptada à vida atual dos cristãos". Depois do encerramento do Sínodo, fiz meu este desejo, considerando que ele "corresponde à verdadeira necessidade da Igreja universal e das Igrejas particulares". Como não havemos de agradecer de todo o coração ao Senhor, neste dia em que podemos oferecer a toda a Igreja, com o título de "Catecismo da Igreja Católica", este "texto de referência" para uma catequese renovada nas fontes vivas da fé!

(JOÃO PAULO II, Fidei Depositum, p.1, 1992)

Estas controvérsias vêm ocorrendo em meios cuja instrução é privilegiada, pode-se imaginar o que não esteja acontecendo nos meios de formação de base. ${ }^{11}$ Vê-se com urgência a necessidade de um ensino claro, em torno deste e de outros temas, para saúde espiritual do fiel cristão e seu discernimento intelectual.

O objetivo geral deste trabalho é oferecer dados argumentativos embasados na Bíblia, Tradição e Magistério da Igreja Católica a cerca do mal e da existência do Diabo na doutrina católica.

Este artigo se realizou com a consulta de textos expostos na bibliografia e como norteadores: o Denzinger-Hunermann $(\mathrm{DH})^{12}$ e o atual Catecismo da Igreja Católica $(\mathrm{CIC})^{13}$, não perdendo de vista as Sagradas Escrituras como fonte primária e os

\footnotetext{
${ }^{11}$ Nas salas de catequese para primeira comunhão, crisma e estudos bíblicos, nas paróquias pelo mundo.

${ }^{12}$ Denzinger e Hunermann(DH) é um compêndio das definições e símbolos da Igreja, nele está contido as elaborações teológicas através de documentos oficiais desde o século I na sua língua original e traduzido.

13 O Catecismo da Igreja Católica é um manual onde esclarece as questões principais da doutrina que o Magistério refletiu durante
} 
comentários exegéticos de duas traduções teológicas distintas como incremento no debate. Os demais livros servem como referências de autores que se atém a este estudo, sejam no campo doutrinário ou pastoral. Salientamos os estudos do Monsenhor Corrado Balducci sj. conhecido demonólogo e exorcista da Arquidiocese de Roma citado como fonte fidedigna pelo Dicionário de Espiritualidade (ANCILLI, 2012). Este e outros autores apenas como reforço da própria doutrina católica e para avolumar o debate pastoral.

3. Conceito de mal e conceito de diabo

O conceito de mal e do diabo, embora pareçam que se fundem no imaginário popular, é necessário esclarecer que são duas coisas diferentes.

O mal geralmente é o nome dado a atos que vão contra a lei. No caso da doutrina católica o que vai contra o caminho proposto por Cristo é o mal. ${ }^{14}$ Ele como a Verdade vem trazer vida em abundância, então preenche a existência com o "bem", substância de Deus que está em toda criação. Então o mal seria o esvaziamento deste bem, assim gera consequências contrárias à vida e a verdade. Respectivamente a morte e a mentira. Neste dualismo, na existência da pessoa humana, também se pode utilizar os símbolos de "amor" e "ódio", o primeiro, como o bem: gera e preenche a vida. O segundo esvazia e destrói a vida. Estes aspectos subjetivos estão mais pra uma reflexão filosófica que teológica, no entanto é preciso esta reflexão filosófica para estabelecer a conexão racional com base nas Sagradas Escrituras entre o que é mal e a criatura Diabo. No séc. IV d.C. Santo Agostinho se deteve nestas elaborações para explicar que o mal não provém de Deus e esclarece que o que parece mal, dos atos vindos de Deus, em verdade é a justiça:

[...] Tomamos o termo "mal" em dois sentidos: um, ao dizer que alguém praticou o mal; outro, ao dizer que sofreu algum mal. [...] Pois bem, se sabes ou acreditas que Deus é bom - e não nos é permitido pensar de outro modo -, Deus deve distribuir recompensas aos bons, assim como castigos aos maus. E por certo, tais castigos parecem males àqueles que os padecem. É porque, visto ninguém ser punido injustamente - como devemos acreditar, já que, de acordo com a nossa fé, é a divina 
Providência que dirige o universo -, Deus de modo algum será o autor do primeiro gênero de males a que nos referimos, só do segundo. [...] o mal não poderia ser cometido sem ter algum autor. [...] cada pessoa ao cometê-lo é o autor de sua má ação. Se duvidas, reflete no que já dissemos acima: as más ações são punidas pela justiça de Deus. Ora, elas não seriam punidas com justiça, se não tivessem sido praticadas de modo voluntário (O livre arbítrio, p.25-26).

O chamado pecado ou iniquidade cometida por qualquer criatura é o mal. Rejeitar as leis da vida do chamado a vida é o mal. Este mal terá influência de um jeito ou de outro na sociedade, podendo constituir um pecado estrutural ou o mal na sociedade, o que influenciará as novas gerações de seres humanos. Deus sendo bom, não coopera com o mal, tudo que Ele cria é bom e quer que permaneça bom. No entanto, as criaturas podem por vontade livre praticar ações más. Desta forma, trazer sobre si a destruição, o inferno, a condenação. A doutrina católica ilumina com as seguintes definições: “O mal é a carência do bem (DH 3251); o mal não é uma substância ou natureza, mas um castigo para substância 286, 457, 874”(DH c:1fa). O mal não tendo substância então precisa que aqueles que tem substância esvaziem-na, para que o mal se faça presente. O esvaziamento de Deus, o esvaziamento do amor pelo próximo tem por consequência o mal.

Quando tratamos de atos é necessário atribuir responsáveis, se Deus é responsável pela Criação e toda criação é boa, assim como, se Deus for responsável pelo mal Ele será contraditório em sua ética ou será necessário dividi-Lo em dois. Neste caso se tratará de outro conceito doutrinário não católico: O maniqueísmo. Sobre esta questão do mal e das criaturas esvaziadoras do bem o Papa Leão I em 21 de julho de 447 esclarece:

Dizem que o diabo nunca foi bom e que sua natureza não é obra de Deus, mas que ele emergiu do caos e das trevas: a saber, porque não tem autor algum, mas é ele mesmo a substância de todo o mal, enquanto a verdadeira fé... professa que a substância de todas as criaturas, quer espiritual quer corporal, é boa e que não há nenhuma natureza do mal; pois Deus, que é criador de todas as coisas, não fez nada que não fosse bom. Dai <se segue> também que o Diabo seria bom se permanecesse no <estado em> que foi feito. Mas, porque usou mal sua excelência natural e "não permaneceu na verdade" (Jo 8,44), não passou para uma substância contrária, mas 
desligou-se do sumo bem ao qual deveria aderir, assim como os mesmos que afirmam tais coisas caem da verdade na falsidade e acusam a natureza naquilo em que por própria vontade cometem falta e são condenados por causa de sua voluntária perversidade. De qualquer modo, o mal estará neles, e o mal mesmo não será a substância, mas castigo para a substância (DH 286).

A Igreja primitiva expõe nos seus escritos sobre aqueles que são batizados: "sabemos que ninguém que nasceu de Deus peca, porque o preserva Aquele que foi gerado por Deus, e o Maligno, assim, não o atinge. Sabemos que somos de Deus e que o mundo inteiro está sujeito ao Maligno" (1Jo 5,18-19). Entretanto, as criaturas portadoras de consciência e vontade persistem no pecado, o objetivo dos sacramentos, exercícios espirituais é para não utilizar o livre arbítrio para errar. A liberdade pode ser um peso quando a criatura se afasta de seu Criador, querendo "ser como deuses" (cf. Gn 3,4). No caso, anjos e seres humanos, têm esta capacidade de escolha e esta possibilidade de praticar a iniquidade, esvaziar o bem e promover o mal o que gerará consequências para suas próprias existências.

Em Gênesis $(3,1 \mathrm{ss})$ a serpente influencia os primeiros pais a rejeitar as leis de Deus, instigou a soberba, o orgulho, o ser sem Deus. "A serpente disse então à mulher: Não, não comereis! Mas Deus sabe que, no dia em que dele comerdes, vossos olhos se abrirão e vós sereis como deuses, versados no bem e no mal” $(3,4)$. Neste texto, independente da alegoria que se adote, fica claro que uma criatura antes da humanidade pecou, esta é identificada como o antigo Inimigo, que João no Apocalipse identifica como Satã ou o Diabo:

Houve então uma batalha no céu: Miguel e seus Anjos guerrearam contra o Dragão. O Dragão batalhou, juntamente com seus Anjos, mas foi derrotado, e não se encontrou mais um lugar para eles no céu. Foi expulso o grande Dragão, a antiga Serpente, o chamado Diabo ou Satanás, sedutor de toda terra habitada - foi expulso para terra, e seus Anjos foram expulsos com ele (Ap 12,7-9).

Sendo assim, as Sagradas Escrituras iniciam e finalizam com esta criatura avessa ao Reino de Deus, que o $\mathrm{CIC}^{15}$ confirma como sendo o Mal na oração do "Pai nosso":

${ }^{15}$ Catecismo da Igreja Católica 
A última petição ao nosso Pai também está incluída na oração de Jesus: "Não peço que os tires do mundo, mas que os guardes do Maligno" (Jo 17, 15). Ela diz-nos respeito, a cada um pessoalmente, mas somos sempre «nós» que rezamos, em comunhão com toda a Igreja, pela libertação de toda a família humana. A oração do Senhor não cessa de nos abrir às dimensões da economia da salvação. A nossa interdependência no drama do pecado e da morte transforma-se em solidariedade no corpo de Cristo, em "comunhão dos santos». Nesta petição, o Mal não é uma abstração, mas designa uma pessoa, Satanás, o Maligno, o anjo que se opõe a Deus. O «Diabo» («dia-bolos») é aquele que "se atravessa» no desígnio de Deus e na sua «obra de salvação» realizada em Cristo.

"Assassino desde o princípio, [...] mentiroso e pai da mentira" (Jo 8, 44), "Satanás, que seduz o universo inteiro" (Ap 12, 9), foi por ele que o pecado e a morte entraram no mundo, e é pela sua derrota definitiva que toda a criação será liberta do pecado e da morte. "Sabemos que ninguém que nasceu de Deus peca, porque o preserva Aquele que foi gerado por Deus, e o Maligno, assim, não o atinge. Sabemos que somos de Deus e que o mundo inteiro está sujeito ao Maligno" (1 Jo 5, 18-19):

O Senhor, que tirou o vosso pecado e perdoou as vossas faltas, tem poder para vos proteger e guardar contra as insídias do Diabo que vos combate, para que não vos surpreenda o inimigo que tem o hábito de engendrar a culpa. Mas quem a Deus se entrega não tem medo do Diabo. Porque "se Deus está por nós, quem contra nós?" (Rm 8, 31).

A vitória sobre o «príncipe deste mundo» foi alcançada, duma vez para sempre, na «Hora» em que Jesus livremente Se entregou à morte para nos dar a sua vida. Foi o julgamento deste mundo, e o príncipe deste mundo foi «lançado fora». "Pôs-se a perseguir a Mulher" (Ap 12,13), mas não logrou alcançá-la: a nova Eva, "cheia da graça» do Espírito Santo, foi preservada do pecado e da corrupção da morte (Imaculada Conceição e Assunção da santíssima Mãe de Deus, Maria, sempre Virgem). Então, "furioso contra a Mulher, foi fazer guerra contra o resto da sua descendência" (Ap 12,17). Eis porque o Espírito e a Igreja rogam: "Vem, Senhor Jesus!" (Ap 22, 17.20), já que a sua vinda nos libertará do Maligno (CIC 2850-2853). 
Esta criatura espiritual é um anjo criado bom, que se corrompeu, afastando-se de Deus e influenciando outros anjos neste caminho da iniquidade. "[...] Pois o Diabo e os outros demônios foram criados por Deus naturalmente bons, mas por si mesmos se transformaram em maus. Já o homem pecou por sugestão do Diabo. [...]” (DH 800). Nas Sagradas Escrituras estes outros anjos caídos são chamados genericamente de daimonia (daimonion) "palavra grega de etimologia incerta" (ANCILLI, 2012, p.743) este neologismo por vezes é atribuído à tradição dos mitos gregos e da linguagem religiosa grega, para identificar espíritos que podiam ser bons ou maus "enviados pelas divindades chamados daimons" (RUSCONI, 2003, 114), (cf. Wikipedia, daimon, 24/10/2013), no entanto os escritores inpirados distinguem a palavra daimonia e o plural daimonion de daimon para tratar das criaturas reais chamadas também de espíritos impuros, este distinção deve ser observada principalmente quando estas palavras são utilizadas como substantivo e como adjetivo, os textos originais deixam claro quando retrata as criaturas e quando se refere a qualidade. $\mathrm{O}$ aparecimento deste nome na tradução grega da Bíblia hebraica (septuaginta séc. III a.C.) "substituindo ídolos pagãos pela palavra demônio" (QUEVEDO, 2005, p.371) não retira a força destas palavras no Novo Testamento, mas reafirma a sua existência, por meio destas, das criaturas espirituais avessas a Deus e influenciadoras do homem, no insistente combate interposto por Jesus Cristo:

Por que não reconheceis minha linguagem? É porque não podeis escutar minha palavra. Vós sois do Diabo, vosso pai, e quereis realizar os desejos de vosso pai. Ele foi homicida desde o princípio e não permaneceu na verdade: quando ele mente, fala do que lhe é próprio, porque é mentiroso e pai da mentira. Mas porque digo a verdade, não credes em mim (Jo 8, 44-45).

A tese da existência de Satã e os demônios e a influência destes na vida humana se mantém de forma sólida na doutrina católica no decorrer dos séculos.

Isto se deve em boa parte pela conexão com outro elemento doutrinário: o Pecado Original. Primeiro pecado cometido pelos primeiros pais (cf. DH 1511-12) este recaiu sobre todas as demais gerações humanas e estas se tornaram escravas de Satã, assim conhecendo a morte.

Desta forma, o mal está no pecado que as criaturas cometem, não obrigatoriamente, mas por livre escolha. Por mais que Satã e os demônios possam 
influenciar, a última decisão sempre será a da pessoa humana. Por sinal, nas biografias dos santos estes Inimigos surgem como elementos importantes na forja de seus espíritos. Assim foi o caso de São Pio de Pietrelcina (cf.PERONI, 2002, p.99), cujo testemunho é tão recente que viveu para presenciar o Concílio Vaticano II, morrendo em 1968 e sendo canonizado em 2002, da mesma forma conta os Doutores da Igreja Santo Atanásio (séc IV) sobre a "Vida de Santo Antão" e São Gregorio Magno (séc. VI) sobre a "Vida de São Bento".

Algo que não se pode deixar fora da discussão é como as estruturas de pecado influenciam o livre arbítrio. Por vezes o homem se depara em circunstâncias que ele pratica o mal com aprovação social. Principalmente quando se fala em sobrevivência, bem estar e desenvolvimento. Conforme questiona João Paulo II em audiência (RV, 25/08/1999) quando discorreu sobre o pecado pessoal e as estruturas de pecado. Ele inicia o ensino com a seguinte declaração: "Olhemos, antes de tudo, para a atitude de Jesus que veio precisamente para libertar os homens do pecado e da influência de Satanás." Após fundamentar esta introdução, expõe a delicada linha que separa a liberdade humana, seu livre arbítrio, e as influências do Maligno incrustadas na sociedade:

Contudo, é um facto incontestável, como várias vezes tive ocasião de reafirmar, que a interdependência dos sistemas sociais, econômicos e políticos, cria no mundo de hoje múltiplas estruturas de pecado (cf. Sollicitudo rei socialis, 36; Catecismo da Igreja Católica, n. 1869). Existe uma tremenda força de atracção do mal que faz julgar «normais»e «inevitáveis» muitas atitudes. O mal aumenta e faz pressão com efeitos devastadores sobre as consciências, que permanecem desorientadas e nem sequer são capazes de discernir. Se se pensa depois nas estruturas de pecado que detêm o desenvolvimento dos povos mais desfavorecidos sob o aspecto econômico e político (cf. Sollicitudo rei socialis, 37), chegar-se-ia como que a ceder diante de um mal moral que parece irresistível.

Sabe-se, conforme João $(12,31)$ e notas, que o Filho de Deus se encarnou para vencer todo mal e o Senhor deste mundo:

“[...] O reino de Satã sobre o mundo (Jo 14,30; 16,11; 1Jo $5,19)$ terminará por ceder lugar ao reino de Cristo (Ap 12,9-10). Essa dupla realeza deve ser compreendida na 
perspectiva ética. O Diabo é mentiroso por natureza. Desde as origens enganou a humanidade a respeito dos mandamentos divinos, o que lhe acarretou a morte; é portanto homicida (Jo 8,44b; Gn 3; Sb 2,24). As autoridades judaicas que querem matar Jesus fazem por instigação do Diabo (Jo 8,44a) como outrora Caim (1Jo 3,12 ). É o príncipe deste mundo que, por suas mentiras, é a causa de todas as desordens morais (cf. Ef 2,1-3; 6,1017; 2Co 4,4). Seu reino é o do Mal, e gera a morte. Cristo, ao contrário, foi enviado por Deus para nos dizer a verdade, esta verdade que deve nos tornar livres da escravidão do Diabo (BÍBLIA DE JERUSALÉM, 2008, nota e, p.1875).

Jesus venceu o Inimigo e de todas as formas deu testemunho do Reino de Deus. No entanto, o ser humano oscila entre estar na graça de Deus por Jesus Cristo e novamente voltar à escravidão de Satã por meio do pecado. Satã mantém seu combate até o fim dos tempos. E este aspecto escatológico a doutrina evidencia no Armaghedon:

Ora a Bíblia, especialmente nos textos apocalípticos, fala do paroxismo a que vai chegar esta luta, enquanto irá convergir numa polarização final, a de um último e encarniçado combate. Eis alguns testemunhos do NT nesta direção:

Jesus diz que o joio cresce junto com o trigo até a hora da ceifa final (Mt 13,30). No "discurso escatológico" (Mt24). Cristo, superpondo o fim de dois mundos, o de Jerusalém e o do cosmos, fala da "grande tribulação" e afirma que, "pelo crescimento da iniquidade, o amor de muitos se esfriará" (v.12). Quem sabe a "tentação" de que fala o pai nosso aluda também ao grande apuro final. Há outrossim a terrível possibilidade da apostasia escatológica: "Quando o Filho do Homem voltar, acaso ainda achará fé sobre a terra?" (Lc 18,8).

São Paulo ensina que antes da parusia do Senhor, sucederá a grande apostasia, a vinda do "homem ímpio, filho da perdição, o adversário, agente do mistério da iniquidade", ministro de "Satanás", o Antideus (2Ts 2,19) (BOFF, 2012, p.108-109).

Também o Concílio Vaticano II reafirma este ensinamento: “A história humana na sua globalidade está marcada por uma luta tremenda contra as potências das trevas; luta que começou logo na origem do mundo e que irá durar, como diz o Senhor, até ao último dia" (GS 37).

Aqui, é importante salientar novamente, não se trata de substância, não existe substância má. Existe atitude má, criaturas que abusam da liberdade ofertada por Deus 
em direção às paixões. Esta distinção entre substância e escolhas também o Concílio de Latrão em 1215 (cf.DH 800) reforçou contra o Maniqueísmo (DH 457) e principalmente, naquele momento, contra o Catarismo, para não cair no erro de considerar Satã outro Deus, até mesmo em ordem de importância, a distância entre um Criador e uma criatura é infinito. Também reafirmou a existência de criaturas espirituais e materiais, assim como o papel do Diabo na economia da Salvação. Afinal Jesus veio para salvar a humanidade do quê, senão do estado de pecado e a consequente escravidão de Satã?

[...] O Pai gera, o Filho nasce, o Espírito Santo procede. São cosubstânciais, co-iguais, co-onipontentes e coeternos: único princípio do universo, criador de todas as coisas visíveis e invisíveis, espirituais e materiais, que com sua força onipotente desde o princípio do tempo criou do nada uma e outra criação: a espiritual e a material, isto é, angelical e a mundana; e, depois, a humana, de algum modo comum <a ambas〉, constituída de alma e corpo. Pois o Diabo e os outros demônios foram criados por Deus naturalmente bons, mas por si mesmos se transformaram em maus. Já o homem pecou por sugestão do Diabo.

Essa santa Trindade, indivisível segundo a comum essência e distinta segundo as propriedades das pessoas, dispensou ao gênero humano, por meio de Moisés, dos outros profetas e dos outros seus servos, a doutrina da salvação, segundo uma disposição dos tempos perfeitamente ordenada [...] (DH 800).

Por fim, o mal não tem substância, o bem sim é Deus. Então o mal é a ausência do bem. Satã e os demônios sendo agentes do mal são esvaziadores do bem na criação. Assim não apenas cometem o mal, o pecado, mas são promotores dele, por esta razão inimigos por excelência de Deus e da humanidade.

4. Quadro das posições teológicas sobre demonologia

Teólogos e outros autores modernos debatem o significado das centenas de aparições das palavras satan, diabolos, daemonia (daemonion) e seus significados nas Sagradas Escrituras. As hipóteses mais difundidas são as do quadro seguinte; 
1) Alguns cogitam a existência de uma criatura espiritual, mas preferem o simbólico (Gonzalez Faus, site: ihu 25/03/2013).

2) Outros negam a existência da criatura espiritual e consideram-na apenas personificação do mal, um arquétipo (SANFORD, 1988, p. 52-54) (SILVA, 2011, 129-134).

3) Há quem afirme a existência da criatura, mas a confundem com o mal (heresia dos maniqueus e cátaros condenados em DH 457 e 800).

4) Outros admitem a existência da criatura e a consideram uma opositora a Deus, mas não influenciadora no mundo (parapsicologia do padre Quevedo).

5) Outros afirmam a existência da criatura, consideram-na uma opositora a Deus e influenciadora de outras criaturas seja espirituais ou humanas a pecar (Doutrina da Igreja Católica: DH 800, DH 1511-12, CIC 2850ss ).

\section{Considerações finais}

As cinco hipóteses acima aparecem de forma recorrente em debates teológicos ou no senso comum, em programas televisivos, filmes, etc...

No meio disso tudo o fiel cristão, pouco instruído, é induzido ao erro.

Talvez o que torna mais preocupante é o fiel cristão oscilar entre uma e outra hipótese, como se isto fosse coerente com a fé que ele professa. Exemplos cotidianos vêm expor este quadro: o mais trivial é a interpretação popular do Diabo como sendo o mau hábito. Desta forma não existe a criatura, mas sim as atitudes más são o Diabo (confusão entre criatura e substância). O Diabo não é o mal, ele tornou-se mau. E muito menos é aquele que pratica o mau hábito por qualquer um. Quando se traduz o fim do "Pai nosso" com "mal" contribui com esta confusão, mesmo colocando mal com a inicial maiúscula não traduz o sentido mais apropriado que seria o Maligno. A questão da pessoa do anjo caído que foi o primeiro responsável por espalhar a iniquidade pela criação e que continua influenciando com toda força angélica levando outros a pecar, já 
vista na exposição do CIC (2850-2853). Assim, influenciar ao mal é completamente diferente de ser o mal. No I Sínodo de Braga (561 d.C.) esta questão foi resolvida na seguinte declaração:

Se alguém diz que o Diabo não foi anteriormente um anjo bom feito por Deus e que a sua natureza não foi obra de Deus, mas diz que ele saiu do caos e das trevas e que não há quem o tenha criado, sendo ele mesmo o princípio e também a substância do mal, como dizem Maniqueus e Priscilianos, seja anátema (DH 457).

Outro equívoco popular é atribuir ao Diabo as más escolhas pessoais. O quietismo foi condenado no século XVII (DH 2269) justamente difundir esta forma de pensar. Isto pode gerar a irresponsabilidade sobre a própria vida do fiel, irresponsabilidade sobre o próprio batismo, do livre arbítrio em Cristo. Errado é também atribuir a ele também a criação seja de criaturas seja de forças da natureza. $\mathrm{O}$ mesmo Sínodo esclarece: "Se alguém crê que o Diabo tenha feito algumas criaturas no mundo e que o Diabo mesmo faça com autoridade própria trovões, raios, tempestades e secas, como o diz Prisciliano, seja anátema” (DH 458). Sendo assim, estabelece-se desde o século VI um ponto pacífico na doutrina da Igreja Católica: que Satã existe, é uma criatura espiritual, criada boa por Deus, induz as criaturas à iniquidade, utiliza-se da concupiscência humana, para que o homem saia da graça santificante de Deus e caia no estado de morte, o pecado. No entanto, tem uma força limitada, pois ele não é o próprio mal e não é criador, apenas comete o mal e perverte a criação, por livre escolha como qualquer outra criatura que recebe de Deus esta liberdade. Sobre estas questões os Doutores da Igreja refletem:

O Diabo pode fazer mal ao homem, mas apenas dentro dos limites da permissão de Deus. São Tomas de Aquino cita Santo Agostinho dizendo que há muitas coisas que os demônios poderiam fazer por causa de sua natureza, mas eles não podem por causa da proibição divina (cf. De malo, 16, 11, ad 10). Seria de fato terrível se Deus não restringisse sua atividade maligna. Santo Agostinho disse: "Se o diabo pudesse fazer tudo o que quer, não restaria um único ser humano vivo na Terra" (PL XXXVII, 1246). São Boaventura disse: "A crueldade do diabo é tal que ele nos devovaria a qualquer momento se o poder divino não nos protegesse" (Diaeta salutis, VII, cap.1) (BALDUCCI, 2004, p.107-108). 
Também o Papa Francisco numa missa em sufrágio pelo Bispos e Cardeais falecidos discorre:

\begin{abstract}
Mesmo as potências demoníacas, hostis ao homem, se detêm impotentes diante da íntima união de amor entre Jesus e quem o acolhe com fé. Essa realidade do amor fiel que Deus tem para com cada um de nós ajuda-nos a enfrentar com serenidade e força o caminho de cada dia, que por vezes é rápido, por vezes, ao invés, é lento e árduo. Somente o pecado do homem pode romper esse laço (RV $\left.{ }^{16}, 04 / 11 / 2013\right)$.
\end{abstract}

É importante salientar que embora limitada à ação de influência destas criaturas espirituais é proporcional à abertura humana. Existe a livre escolha em direção ao mal e isto certamente abre as portas para ação diabólica na vida. Sobre como identificar isto, que parece tão abstrato no cotidiano, "o Papa Paulo VI nos ofereceu algumas diretrizes a este respeito" (BALDUCCI, 2004, p.116):

[...] Existem sinais, e quais são, da presença da ação diabólica? E quais são os meios de defesa contra tal perigo traiçoeiro?

Devemos ser muito cautelosos para respondermos a primeira questão, mesmo se os sinais do Maligno parecem evidentes... Podemos admitir sua ação sinistra onde a negação a Deus torna-se radical, súbita e absurda; onde mentiras hipócritas e óbvias são apresentadas contra a verdade evidente; onde o nome de Cristo é rejeitado com ódio intenso e revoltoso (cf. 1Cor 16, 22 e 12, 3); onde o espírito do Evangelho é negado e levado por água abaixo; onde o desespero tem a última palavra [...] $\left(\mathrm{OR}^{17}\right.$, 23/11/1972).

O Papa Francisco somente em $2013^{18}$ proferiu o ensino a cerca deste tema por nove vezes. Deixando clara a importância do mesmo nas realidades atuais da relação févida, isto não quer dizer que se deva retornar para uma pedagogia do medo ou uma teologia do medo, isto certamente deve ser superado, ao contrário, apresentando o problema chama a atenção para o cuidado que o cristão deve ter com sua Salvação, não se esquecer de se manter atento, voltado a Deus e no amor ao próximo, para que as

\footnotetext{
${ }^{16}$ Radio Vaticana

${ }^{17}$ Osservatore Romano

${ }^{18}$ Radio Vaticana: 14/03/2013, 04/2013, 04/05/2013, 12/06/2013, 18/07/2013, 02/09/2013, 05/10/2013, 11,10,2013, 01/11/2013 ...
} 
consequências do mal não estejam presentes em sua vida.

Referências

ANCILLI, Ermano e Pontifício Instituto Teresianum, Dicionário de espiritualidade, São Paulo, Paulus/Loyola, 2012.

BALDUCCI, Corrado, O Diabo "vivo e atuante no mundo”, São Paulo, MIR, 2004.

Biblia de Jerusalém, São Paulo, Paulus, 2008.

Bíblia sagrada, Santos Evangelhos, Braga, Edições Theologica, 1995.

Bíblia sagrada, Atos dos apóstolos e epístolas, Braga, Edições Theologica, 1990.

Bíblia sagrada, epístolas II, aos hebreus, católicas e apocalipse, Braga, Edições Theologica, 1993.

Catecismo da Igreja Catolica, Disponível em: http://vatican.org, Acesso em: 24ago.2014.

BOFF, Clodovis M., Escatologia: Breve tratado teológico-pastoral, São Paulo, Ave Maria, 2012.

BOFF, Clodovis M., Teoria do método teológico, Petropolis, Vozes, 2009.

DENZINGER, Heinrich, Compêndio dos símbolos, definições e declarações de fé e moral. Denzinger - Hünermann, São Paulo: Paulinas: edições Loyola, 2007.

MARCON, Marco Antonio, Satã e os demônios na doutrina católica e suas implicações na pastoral, Caderno teológico PUCPR, V.1 n.1, 2013. Acessado em 21/08/2014: http://www2.pucpr.br/reol/index.php/teologico?dd99=pdf\&dd1=12259

QUEVEDO, Oscar, Antes que os demônios voltem, São Paulo, Loyola, 2005.

SANFORD, John A., Mal, o lado sombrio da realidade. , São Paulo, Paulus, 2007.

SILVA, V. da. Revista Pistis e Praxis: teologia e pastoral vol3 num1, Curitiba, PUCPR, 2011.

VÁRIOS AUTORES, Dicionário Hebraico-português e aramaico-portugues, São Leopoldo: Sinodal, Petrópolis: Vozes, 1987

RUSCONI, Carlo, Dicionário do grego do novo testamento, São Paulo: Paulus, 2003.

SANTO AGOSTINHO, O Livre arbítrio, São Paulo: Paulus, 2ª edição, 1995.

SANTO ATANÁSIO, Vida de Santo Antão, Petrópolis, Vozes, 2000.

SÃO GREGORIO MAGNO, Segundo livro dos diálogos, vida de São Bento. Disponível em: http://cristianismo.org.br Acesso em: 02set.2013.

VATIVANO.ORG, Audiência João Paulo II 25/08/1999, disponível em:http://www.vatican.va/holy_father/john_paul_ii/audiences/1999/documents/hf_jpii_aud_25081999_po.html Acesso em: 11nov.2013

Recebido: $25 / 04 / 2014$

Received: 04/25/2014

Aprovado: 19/07/2014

Approved: 07/19/2014 